\title{
Problem Based Learning pada Materi Pembuatan Pola Busana Pesta Wanita
}

\author{
Kurnia Izati*, Nur Endah Purwaningsih, Endang Prahastuti \\ Universitas Negeri Malang, Jl. Semarang No. 5 Malang, Jawa Timur, Indonesia \\ *Penulis korespondensi, Surel: nur.endah.ft@um.ac.id
}

Paper received: 05-02-2021; revised: 18-02-2021; accepted: 30-02-2021

\begin{abstract}
Abstrak
Tujuan penelitian ini untuk mengetahui bagaimana penerapan model pembelajaran Problem Based Learning pada materi pembuatan pola busana pesta wanita. Penelitian ini menggunakan metode eksperimental pretest-postest group design. Populasi penelitian ini berjumlah 62 siswa pada kelas XII TB yang terdiri dari 2 kelas. Sampel penelitian adalah kelas XII TB 1 untuk kelas eksperimen dan XII TB 2 untuk kelas control. Menggunakan tes praktik membuat pola busana pesta wanita. Hasil uji validitas menunjukkan sebesar 0.556 dan 0.969 , hasil uji reliabilitasnya sebesar 0.867 dan 0.579 . Hasil uji seluruh data bersifat valid dan reliable. Hasil dari pretest pada kelas eksperimen mendapatkan nilai 75.28, untuk meningkatkan pemahaman siswa terkait dengan cara membuat pola. Dikarenakan kebanyakan siswa tidak faham dengan cara membuat pola ketika model busana yang dibuat agak sulit. Setelah peneliti melakukan treatment, peneliti melakukan posttest. Hasil posttest kelas eksperimen meningkat sebesar 85.68, sedangkan tanggapan siswa diperoleh angka $84.02 \%$. model yang digunakan membuat peserta didik lebih paham tentang konsep pembelajaran. sedangkan pada kelas control didapatkan nilai rata-rata posttest sebesar 80.9. dikarenakan peserta didik hanya secara pasif menerima pengetahuan dari guru dan merasa sulit untuk mengembangkan konsep dan pemahaman. Kesimpulan dalam penelitian ini yaitu, model pembelajaran Problem Based Learning sangat baik penerapannya, serta dapat meningkatkan hasil belajar siswa.
\end{abstract}

Kata kunci: model pembelajaran; problem based learning; pola busana pesta wanita

\section{Pendahuluan}

Pemahaman tentang pendidikan Tata Busana dapat diperoleh dari berbagai sumber. Salah satu materi pembelajaran di bidang Tata Busana adalah materi tentang pembuatan pola busana pesta wanita. Pada mata pelajaran ini siswa mempelajari tentang pengambilan ukuran sampai dengan pecah pola. Peneliti melakukan observasi awal menunjukkan bahwa kelas XII Tata Busana 1 SMK Negeri 7 Malang, terdapat banyak siswa yang kurang paham tentang pemahaman tentang pembuatan pola. Pada nilai praktek pola blazer terdapat 22 dari 32 murid yang mendapatkan nilai dibawah KKM (78), siswa tersebut terlihat masih bergantung pada guru pengajar. Sehingga menurut peneliti guru memerlukan perbaikan proses belajar mengajar.

Model pembelajaran juga berpengaruh terhadap proses belajar mengajar. Salah satunya adalah model Problem Based Learning. Problem Based Learning adalah model yang menyajikan masalah dunia nyata sebagai pendekatan (Nafiah dan Suryanto, 2014). Siswa dapat menyelesaikan permasalahan dengan pengetahuan yang ada dan dapat bekerja sama dengan kelompok. Banyak keutamaan dalam model ini, salah satunya meningkatnya hasil belajar. Keutamaan tersebut akan terwujud dengan baik apabila pelaksanaannya dijalankan dengan baik dan sesuai langkah kerja. Peran kerjasana yang baik antara guru dan siswa juga berperan penting untuk mewujudkan pembelajaran yang baik (Kurniasih dan Sani, 2015).

Terdapat beberapa tahapan dalam pelaksanaan model pembelajaran Problem Based Learning diantaranya: 1) proses orientasi murid pada masalah, 2) mengorganisisr siswa, 3) 
membimbing penyelidikan individu maupun kelompok, 4) mengembangkan dan menyajikan hasil, 5) melakukan analisis dan evaluasi proses dan pemecahan masalah (Trianto, 2007). Model tersebut merupakan model yang melibatkan siswa untuk memecahkan masalah, sehingga siswa dapat mempelajari pengetahuan mengenai masalah dan memecahkan masalah tersebut. Menurut peneliti model pembelajaran ini cocok diterapkan pada materi pembuatan pola busana pesta wanita. Siswa akan mempelajari masalah dalam pembuatan pola dan belajar untuk memecahkannya (Ward dalam Ngalimun, 2016).

\section{Metode}

Penelitian ini menggunakan metode eksperimen pretest-posttest control group design. Sampelnya adalah siswa XII TB 1 di SMK Negeri 7 Malang sebagai kelompok eksperimen dan XII TB 2 sebagai kelas control. Kedua kelompok yang telah dipilih kemudian diambil nilai pretestnya untuk mengetahui adakah perbedaan keadaan awal kedua kelas tersebut. Sumber data berupa tes serta angket penelitian. Pelaksanaan penelitian dilakukan dengan memberikan treatmen pada kelas eksperimen, sedangkan pada kelas control dengan menggunakan model pembelajaran konvensional. Bertujuan untuk mengetahui bagaimana penerapan model pembelajaran Problem Based Learning di materi pembuatan pola busana pesta wanita pada kelas eksperimen.

Temuan data pada kelas eksperimen dilakukan dengan uji-t, sebelum melakukan uji-t, syarat yang dilakukan adalah uji normalitas dan uji homogenitas. Pada kelas eksperimen diperoleh data sebesar 0,200 , sedangkan nilai signifikan hasil belajar pretest kelas control sebesar 0,161 dan posttest sebesar 0,79. Semua nilai signifikansi dari masing-masing variable lebih dari 0,05 , data tersebut terdistribusi normal. Sedangkan untuk uji homogenitas menghasilkan data nilai signifikan hasil belajar $(0,079>0,05)$, maka semua data tersebut terdistribusi homogeny.

\section{Hasil dan Pembahasan}

Berdasarkan hasil data, diperoleh $t_{\text {hitung }}$ negative, hasilnya $t_{\text {hitung }}<t_{\text {tabel }}(-12,169<2,000)$ signifikansinya kurang dari $0,05(0,000<0,05)$ artinya terdapat perbedaan yang signifikan antara nilai pretest dengan posttest pada kelas eksperimen setelah diberi perlakuan, nilai hasil belajar setelah perlakuan lebih tinggi dari nilai sebelum perlakuan. Artinya, penerapan model pembelajaran tersebut dapat meningkatkan nila belajar pada materi pembuatan pola busana pesta wanita pada siswa kelas XII TB 1 SMK Negeri 7 Malang. Tanggapan siswa mengenai model ini memperoleh angka sebesar 84,02\%, dalam kriteria interprestasi skor hal tersebut berarti sangat baik. Artinya siswa setuju bahwa model tersebut sangat baik penerapannya pada materi pembuatan pola busana pesta wanita di XII TB 1 SMKN 7 Malang.

\section{Simpulan}

Terdapat kenaikan rata-rata nilai hasil belajar yang sebelumnya mendapat nilai 75,28 meningkat menjadi 85,68, seluruh siswa mendapat nilai diatas KKM, yaitu diatas nilai 78 . Penggunaan model di materi pembuatan pola lebih bagus penerapannya daripada konvensional. Rata-rata kelompok perlakuan $(85,68)$ lebih baik dari pada kelompok control $(80,9)$. Tanggapan siswa mengenai model pembelajaran memperoleh angka $84,02 \%$. Mayoritas siswa menjawab sangat setuju dan setuju, artinya menurut siswa model pembelajaran ini sangat baik penerapannya pada materi pembuatan pola busana pesta wanita di XII TB 1. 
Jurnal Inovasi Teknik dan Edukasi Teknologi (JITET), 1(2), 2021, 95-97

\section{Daftar Rujukan}

Arikunto, S. (2003). Dasar-Dasar Evaluasi Pendidikan. Yogyakarta: Bumi Aksara Cipta

Kurniasih, I \& Sani B. (2015). Implementasi Kurikulum 2013Konsep dan Penerapannya. Surabaya: Kata Pena

Nafiah, Y. N. (2014). Penerapan Model Problem Based Learning untuk Peningkatan Keterampilan Berfikir Kritis dan Hasil Belajar Siswa. Jurnal Pendidikan Vokasi, 4(1), 125 143. DOI: https://doi.org/10.21831/jpv. v4il. 2540

Suprijono, A. (2009). Cooperative Learning Teori dan Aplikasi Paikem. Yogyakarta: Pustaka Pelajar 